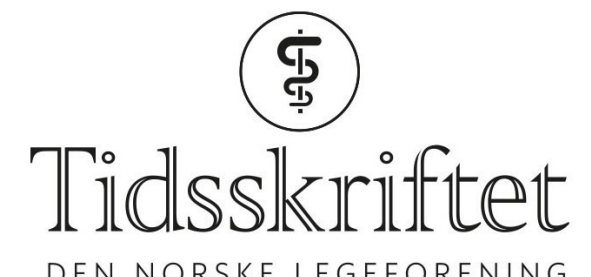

DEN NORSKE LEGEFORENING

\title{
A.L. Brantsæter og medarbeidere svarer
}

KOMMENTAR

\section{ANNE LISE BRANTSAETER}

E-post: annelise.brantsaeter@fhi.no

Anne Lise Brantsæter er seniorforsker ved Folkehelseinstituttet.

MARIANNE HOPE ABEL

TINE HELLE MARGRETE MELTZER

LISBETH DAHL

JAN ALEXANDER

LIV ELIN TORHEIM

SIGRUN HENJUM

Ingen av forfatterne har oppgitt interessekonflikter.

Kirsten Osty stiller spørsmål om bruk av alger som kilde til jod. I Norge er det økende interesse for bruk av tang og tare (makroalger) som vokser langs kysten og også omsettingen av importerte algeprodukter øker. Dette er ikke uproblematisk. Jodinnholdet i tang og tare kan være svært høyt og ukritisk inntak kan innebære helserisiko, spesielt for gravide, ammende og personer med thyreoideasykdommer. Som vi har understreket i artikkelen, er både lavt og høyt jodinntak assosiert med økt risiko for thyreoideaforstyrrelser.

Jodinnholdet varierer mellom ulike tarearter og mellom prøver av samme art. Norske studier viser at brunalger har de høyeste jodkonsentrasjonene (130-4375 ug per gram tørrvekt)(1). Det betyr at så lite som ett gram tørket taremel fra sagtang, sauetang, sukkertare, fingertare, butare eller stortare vil kunne medføre et jodinntak opptil zo ganger den anbefalte dagsdosen på $150 \mu \mathrm{g}$ og syv ganger den høyeste trygge dagsdosen på $600 \mu \mathrm{g}$ for voksne (2). I tillegg kan disse algene ha et høyt innhold av uønskede stoffer som uorganisk arsen og kadmium (1). Røde og grønne alger som søl og havsalat inneholder derimot små til moderate mengder jod. Mattilsynet og Havforskningsinstituttet arbeider med å skaffe mer kunnskap om trygg bruk av alger og algeprodukter.

I sushi brukes det importerte algeprodukter. Nori-tang, som brukes på utsiden av 
makiruller, inneholder små mengder jod. Wakame, som brukes i sjøgresssalat, og kombutang, som brukes i supper, inneholder derimot mye jod. Grønnalger som spirulina og chorella er dyrket i ferskvann og inneholder minimalt med jod.

I helsekostbutikker selges hovedsakelig importerte tang- og tareprodukter, men den norske andelen er $ø$ kende. Mengden jod i mange av disse produktene er ikke deklarert. Skal slike produkter brukes daglig, er det nødvendig med pålitelig angivelse av jodinnholdet. I artikkelen refererte vi til en norsk studie som fant svært høye konsentrasjoner av jod i urin fra individer som hadde brukt et kosttilskudd av tare som anvist (3). Mengden jod i urin var langt høyere enn dagdosen anvist på produktet skulle tilsi. Det er derfor grunn til å utvise stor forsiktighet ved bruk av taretilskudd, slik også norske helsemyndigheter anbefaler (4).

LITTERATUR:

1. Duinker A, Roiha IS, Amlund A et al. Potential risks posed by macroalgae for application as feed and food - a Norwegian perspective. Nasjonalt institutt for ernærings- og sjømatforskning (NIFES), 2016. https://issuu.com/nifes-pdf/docs/rapport-makroalger-27-june-final/8 (4.2.2019).

2. EFSA. Summary of Tolerable Upper Intake Levels - version 4.

https://www.efsa.europa.eu/sites/default/files/assets/UL_Summary_tables.pdf(4.2.2019).

3. Brantsæter AL, Knutsen HK, Johansen NC et al. Inadequate Iodine Intake in Population Groups Defined by Age, Life Stage and Vegetarian Dietary Practice in a Norwegian Convenience Sample. Nutrients 2018; 10: 230. [PubMed][CrossRef]

4. Matportalen. Er det trygt å spise tang og tare?

http://www.matportalen.no/uonskedestoffer_i_mat/tema/miljogifter/er_det_trygt_aa_spise_tang_o g_tare (4.2.2019).

Publisert: 11. mars 2019. Tidsskr Nor Legeforen. DOI:10.4045/tidsskr.19.0155

(C) Tidsskrift for Den norske legeforening 2020. Lastet ned fra tidsskriftet.no 